\title{
Al-Madãris
}

VOL. 2, NO. 2, 2021

E-ISSN: 2745-9950

https://journal.staijamitar.ac.id/index.php/almadaris

\section{PELAKSANAAN MANAJEMEN DALAM PEMBELAJARAN AKIDAH AKHLAK DI MTsN SAMUDERA ACEH UTARA}

\author{
Suci Wahyuni \\ Prodi Manajemen Pendidikan Islam STAI Jamiatut Tarbiyah Lhoksukon \\ suciwahyuni9494@yahoo.com
}

\begin{abstract}
This research is conducted to find out how about the planning, implementation and evaluation in the learning moral aqidah at MTsN Samudera North Aceh. This research is a field study with a qualitative descriptive approach. Sources of research consist of primary and secondary data. The researcher was collected the data by using observation, interview and documentation. Data analysis is done by reducing data, presenting data and drawing conclusion on the data that has been collected. While to guarantee the validity of the data, triangulation techniques are used. The results of this study indicated that: First, Planning in the learning of moral aqidah consists of the preparation of steps in learning such as the preparations of lesson plans, syilabus, prota and prosem. Second, the implementation in learning of aqidah morality includes preliminary activities, core activities and ends with closing activities. Third, the evaluasion used in the study of moral aqidah learning includes written tests and non written tests.
\end{abstract}

Keywords: Management, Learning, Moral Aqidah

\section{A. Pendahuluan}

Penggunaan dan perkembangan ilmu pengetahuan dan teknologi (IPTEK) sekarang ini sangat pesat. Untuk mampu mengimbangi perkembangan tersebut dan mampu menggunakannya, maka setiap orang harus mempunyai kesadaran akan kebutuhan pendidikan. Pendidikan yang berkualitas mampu menghasilkan masyarakat yang memiliki kualitas sesuai dengan kebutuhan pada masa kini. 
Untuk mendapatkan pendidikan yang berkualitas, maka dibutuhkan suatu wadah atau lembaga yang menangani pendidikan, salah satunya adalah sekolah.

Sekolah merupakan suatu tempat aktifitas pendidikan yang berupa proses pembelajaran sehingga dapat mencetak generasi muda bangsa yang cerdas, terampil, dan bermoral tinggi. Proses pembelajaran membantu siswa untuk mengembangkan potensi intelektual yang dimilikinya, sehingga tujuan utama pembelajaran adalah usaha yang dilakukan agar intelek setiap pelajar dapat berkembang (Drost, J.J.S,1994: 32).

Salah satu pembelajaran yang dilaksanakan disekolah adalah pembelajaran pada mata pelajaran Akidah Akhlak. Mata pelajaran Aqidah Akhlaq tidak hanya mengantarkan siswa untuk menguasai pengetahuan aqidah dan akhlaq tapi yang terpenting adalah yang menekankan keutuhan dan keterpaduan antara pengetahuan, sikap, dan perilaku sehingga siswa dapat mengamalkan aqidah dan akhlaq dalam kehidupan sehari-hari untuk meningkatkan keimanan dan ketaqwaan siswa serta pencegahan dari akhlaq tercela (Muhaimin, 2004: 310). Untuk menunjang keberhasilan siswa dalam menguasai pelajaran khususnya akidah akhlak tentu dibutuhkan sebuah Manajemen untuk mengelola segala seluk beluk pelaksanaannya.

Berdasarkan fenomena di atas, penulis tertarik untuk mengadakan penelitian tentang "Pelaksanaan Manajemen Pembelajaran Akidah Akhlak di MTsN Samudera". Adapun tujuan dalam penelitian ini adalah untuk menjelaskan perencanaan dalam pembelajaran Akidah Akhlak di MTsN Samudera, untuk mendeskripsikan pelaksanaan dalam pembelajaran Akidah Akhlak di MTsN Samudera, untuk menerangkan evaluasi dalam pembelajaran Akidah Akhlak di MTsN Samudera.

\section{B. Review Literatur}

Pelaksanaan merupakan kegiatan untuk merealisasikan rencana menjadi tindakan nyata dalam rangka mencapai tujuan secara efektif dan efisien (E. Mulyasa, 2002: 2). bahwa Manajemen adalah ilmu dan seni mengatur proses pemanfaatan sumber daya manusia dan sumber-sumber lainnya secara efektif untuk mencapai suatu tujuan tertentu (Hasibuan Malayu, 2004:54). Sehingga dapat disimpulkan bahwa manajemen adalah suatu proses pengaturan sebuah organisasi untuk mencapai tujuan secara efektif dan efisien.

Adapun definisi pembelajaran yang dikemukan oleh Corey dalam Syaiful Sagala (2003: 61) bahaw: "Pembelajaran adalah suatu proses dimana lingkungan seseorang secara disengaja dikelola untuk memungkinkan ia turut serta dalam tingkah laku tertentu dalam kondisi-kondisi khusus atau menghasilkan respons terhadap situasi tertentu, pembelajaran merupakan subset khusus dari pendidikan"

Dapat disimpulkan bahwa Pelaksanaan Manajemen Pembelajaran adalah serangkaian aktivitas dalam melaksanakan pengaturan untuk membelajarkan seseorang atau kelompok sehingga tercapai tujuan yang telah ditentukan. akidah secara etimologis (lughatan), akidah berakar dari kata aqadaya'qidu-aqdan-aqidatan. Aqdan berarti simpul, ikatan, perjanjian yang kokoh. Setelah terbentuk menjadi akidah berarti keyakinan. Relavansi antara kata aqdan 
dan akidah adalah keyakinan itu tersimpul dengan kokoh didalam hati, bersifat mengikat dan mengandung perjanjian (Ilyas Yunahar, 1998: 1). Sedangkan akhlak adalah tingkah laku, perangai tabi'at, watak, moral atau budi pekerti. Dalam Kamus Besar Bahasa Indonesia, akhlak dapat diartikan budi pekerti, kelakuan. Jadi, akhlak merupakan sikap yang telah melekat pada diri seseorang dan secara spontan diwujudkan dalam tingkah laku atau perbuatan. antara lain:

Adapun unsur-unsur dalam manajemen pembelajaran Akidah Akhlak

\section{Perencanaan Pembelajaran Akidah Akhlak}

Perencanaan adalah menentukan apa yang akan dilakukan. Pada hakikatnya bila suatu kegiatan direncanakan terlebih dahulu maka tujuan dari kegiatan tersebut akan lebih terarah dan lebih berhasil. Itulah sebabnya seorang guru harus memiliki kemampuan dalam merencanakan pembelajaran (Abdul Majid,2009: 15).

Adapun perencanaan pembelajaran Akidah Akhlak yang harus dilakukan oleh seorang guru antara lain meliputi:

1) Program Tahunan

Program Tahunan adalah rencana kegiatan yang akan dilakukan, disampaikan kepada siswa dan dikerjakan oleh guru dalam jangka waktu satu tahun (satu tahun ajaran) yang di dalamnya harus memuat Identitas Pelajaran, Kompetensi Dasar, Materi Pokok dan Alokasi Waktu.

2) Program Semester

Program Semester adalah rencana kegiatan yang akan dilakukan, disampaikan kepada siswa dan dikerjakan oleh guru dalam jangka waktu satu semester dan merupakan penjabaran dari program tahunan yang telah dibuat sebelumnya. Di dalamnya harus memuat, antara lain: Identitas Pelajaran, Kompetensi Dasar, Alokasi Waktu, Bulan dan Pekan pelaksanaan.

3) Silabus

Silabus dapat didefinisikan sebagai garis besar, ringkasan, ikhtisar, atau pokok-pokok isi atau materi pelajaran. Pengertian silabus yang dikeluarkan oleh Depdiknas adalah "bentuk pengembangan dan penjabaran kurikulum menjadi rencana pembelajaran atau susunan materi pembelajaran yang teratur pada mata pelajaran tertentu pada kelas/semester tertentu (Nazaruddin, 2007: 126).

4) Rencana Pelaksanaan Pembelajaran (RPP)

RPP merupakan pegangan bagi guru dalam melaksanakan pembelajaran untuk setiap kompetensi dasar. Oleh karena itu, apa yang tertuang di dalam RPP memuat hal-hal yang langsung berkaitan dengan aktivitas pembelajaran dalam upaya pencapaian penguasaan suatu kompetensi dasar. Setiap guru pada satuan pendidikan berkewajiban menyusun Rencana Pelaksanaan Pembelajaran secara lengkap dan sistematis agar pembelajaran berlangsung secara interaktif, inspiratif, menyenangkan, menantang, memotivasi peserta didik untuk berpartisipasi aktif, serta memberikan ruang yang cukup bagi prakarsa, kreativitas, dan kemandirian sesuai dengan bakat, minat, dan perkembangan fisik, serta psikologis peserta didik (Ismail SM, 2009: 139). 


\section{Pelaksanaan Pembelajaran Akidah Akhlak}

Pelaksanaan Pembelajaran merupakan implementasi dari Rencana Pelaksanaan Pembelajaran. Dalam tahap ini, guru harus aktif menciptakan dan menumbuhkan kegiatan belajar sesuai dengan rencana yang telah disusun. Disamping pengetahuan teori belajar mengajar dan pengetahuan tentang siswa, diperlukan pula kemahiran dan keterampilan teknik belajar, misalnya prinsip mengajar, penggunaan alat bantu pengajaran, penggunaan metode mengajar, dan keterampilan menilai hasil belajar siswa

Pelaksanaan Pembelajaran Akidah Akhlak meliputi tiga kegiatan, antara lain:

1) Kegiatan Pendahuluan

Membuka pelajaran merupakan kegiatan awal yang dilakukan guru dalam kegiatan belajar mengajar untuk mengkondisikan siswa agar perhatian dan motivasinya tumbuh baik secara fisik maupun psikis memiliki kesiapan untuk melakukan kegiatan pembelajaran, dengan begitu perhatian siswa akan terpusat pada apa yang dipelajarinya. Adapun Tujuan dari kegiatan membuka pelajaran ini (Supriyadi, 2014: 124) antara lain:

a) Timbulnya perhatian dan motivasi siswa untuk menghadapi tugastugas pembelajaran yang akan dikerjakan.

b) Siswa mengetahui batas-batas tugas yang akan dikerjakan.

c) Siswa mempunyai gambaran yang jelas tentang pendekatanpendekatan yang mungkin diambil dalam mempelajari bagian-bagian dari mata pelajaran.

d) Siswa mengetahui hubungan antara pengalaman yang telah dikuasai dengan hal-hal baru yang akan dipelajari.

e) Siswa dapat menghubungkan fakta-fakta, keterampilan-keterampilan atau konsep-konsep yang tercantum dalam suatu peristiwa.

f) Siswa dapat mengetahui keberhasilannya dalam mempelajari pelajaran itu.

2) Kegiatan Inti

Tugas guru yang utama adalah mengajar. Mengajar merupakan proses penyampaian ilmu pengetahuan kepada siswa (transfer knowledge). Disini guru dituntut untuk mampu menjelaskan materi pelajaran kepada siswa secara profesional. Dalam pelaksanaannya, guru dapat menggunakan metode pembelajaran, media pembelajaran dan sumber-sumber belajar yang relevan dengan tujuan pembelajaran yang akan dicapai. Didalam kegiatan inti unsurunsur yang terdapat didalamnya adalah seperti pengelolaan kelas, penggunaann media dan sumber belajar serta penggunaan metode belajar.

3) Kegiatan Penutup

Kegiatan penutup pelajaran adalah kegiatan yang dilakukan oleh guru untuk mengakhiri kegiatan pembelajaran. Kegiatan ini dimaksudkan untuk memberikan gambaran menyeluruh tentang apa yang telah dipelajari oleh siswa, mengetahui tingkat pencapaian siswa dan tingkat keberhasilan guru dalam proses pembelajaran. Menurut Permendiknas Nomor 4l Tahun 2007 tentang 
Standar Proses Satuan Pendidikan Dasar dan Menengah menjelaskan bahwa yang dilakukan guru dalam kegiatan penutup adalah

a) Bersama-sama dengan siswa membuat rangkuman/kesimpulan pelajaran.

b) Melakukan penilaian dan refleksi terhadap kegiatan yang sudah dilaksanakan secara konsisten dan terprogram.

c) Memberikan umpan balik terhadap proses dan hasil pembelajaran.

d) Merencanakan kegiatan tindak lanjut dalam bentuk pelajaran remedial, program pengayaan, pemberian tugas, baik tugas individual maupun kelompok.

e) Menyampaikan rencana pembelajaran pada pertemuan berikutnya.

\section{Penilaian pembelajaran akidah akhlak}

Penilaian adalah proses pengumpulan dan pengolahan informasi untuk menentukan pencapaian hasil belajar. Penilaian dilakukan secara konsisten, sistematis, dan terprogram dengan menggunakan tes dan non tes dalam bentuk tertulis atau lisan, pengamatan kinerja, pengukuran sikap, penilaian hasil karya berupa tugas, portofolio, dan penilaian diri. Penilaian hasil pembelajaran menggunakan Standar Penilaian Pendidikan dan Panduan Penilaian Kelompok Mata Pelajaran. Dalam buku Zainal Arifin (2012: 15) tujuan dari penilaian ada empat antara lain:

a) Keeping track, yaitu untuk menelusuri dan melacak proses belajar siswa sesuai dengan rencana pelaksanaan pembelajaran yang telah ditetapkan.

b) Checking-up, yaitu untuk mengecek ketercapaian kemampuan siswa dalam proses pembelajaran dan kekurangan-kekurangan siswa selama mengikuti proses pembelajaran.

c) Finding-out, yaitu untuk mencari, menemukan dan mendeteksi kekurangan, kesalahan atau kelemahan siswa dalam proses pembelajaran sehingga guru dapat dengan cepat mencari alternative solusinya.

d) Summing-up, yaitu untuk menyimpulkan tingkat penguasaan siswa terhadap kompetensi yang telah ditetapkan. Hasil penyimpulan ini dapat digunakan guru untuk menyusun laporan kemajuan belajar ke berbagai pihak yang berkepentingan.

Guru dapat melakukan penilaian dengan cara kuis, pertanyaan lisan dikelas, ulangan harian, tugas individu, kelompok, ujian praktek maupun ujian semester. Dengan adanya penilaian, maka guru akan mengetahui sejauh mana siswa menguasai pelajaran yang di ajarkan.

\section{Metodelogi}

Adapun jenis penelitian yang digunakan peneliti adalah penelitian kualitatif, jenis penelitian ini diharapkan dapat diperoleh pemahaman dan penafsiran yang mendalam mengenai makna dari kenyataan dan fakta yang relevan terhadap data yang ada di lapangan. Untuk menajamkan kajian, penelitian ini beralokasikan di MTsN Samudera Aceh Utara. Alasan dipilihnya 
lokasi penelitian tersebut karena di sana terdapat permasalahan yang dijadikan fokus penelitian.

Penelitian ini menggunakan metode deskriptif kualitatif. Menurut Sugiono penelitian deskriptif kualitatif adalah penelitian yang mengungkapkan kondisi objek alamiah (sebagai lawannya adalah eksperimen) dimana peneliti sebagai instrument kunci. Teknik pengumpulan data dilakukan dengan trigulasi (gabungan), analisis data bersifat induktif dan hasil penelitian kuantitatif lebih menekankan makna dari pada generalisasi (Sugiono, 2003: 8). Jadi penelitian ini tidak bertujuan untuk membuktikan hipotesisnya diterima atau ditolak, tapi hanya ditekankan pada pengumpulan data untuk mendeskripsikan keadaan yang sesungguhnya yang sedang terjadi. Untuk mendapatkan data yang lengkap, maka dalam penelitian ini menggunakan metode pengumpulan data yang terdiri dari:

Pertama, observasi adalah pengamatan terhadap suatu objek yang diteliti baik secara langsung maupun tidak langsung untuk memperoleh data yang harus dikumpulkan dalam penelitian, Kedua, Wawancara adalah percakapan dengan maksud tertentu. Percakapan itu dilakukan oleh dua pihak, yaitu pewawancara (interviewer) yang mengajukan pertanyaaan dan terwawancara (interviewee) yang memberikan jawaban atas pertanyaaan itu. Dalam penelitian ini menggunakan metode wawancara terstruktur. Wawancara ini dilakukan peneliti dengan cara terlebih dahulu mempersiapkan bahan pertanyaaan yang akan diajukan dalam wawancara nanti (Djam'an satori dkk,201l: 105). Ketiga, Dokumentasi adalah catatan peristiwa yang sudah berlalu (Sugiyono,2009: 240). Dokumentasi digunakan sebagai teknik pengumpulan data dengan mencari dokumen yang bersifat pribadi dan resmi sebagai sumber data yang dapat dipergunakan untuk memecahkan permasalah dalam penelitian. Dokumen yang digunakan peneliti disini adalah seluruh yang berkaitan dengan Pelaksanaan Manajemen pembelajaran Akidah Akhlak di MTsN Samudera Aceh Utara baik itu RPP, Soal Ulangan, Absensi Siswa ataupun data lainnya.

Setelah peneliti selesai melakukan proses pengumpulan data, selanjutnya peneliti mulai melakukan pengolahan data dan analisis data yang diperoleh dari hasil wawancara, observasi, dan dokumentasi. Sedangkan analisis data yang dilakukan pada penelitian ini adalah untuk mendapatkan informasi yang berarti agar dapat mengungkapkan permasalahan yang sedang diteliti.

Menurut Sugiyono (2009: 240) bahwa:

"Analisis data kualitatif adalah proses mencari dan menyusun secara sistematis data yang diperoleh dari hasil wawancara, catatan lapangan dan dokumentasi, dengan cara mengorganisasikan data ke dalam kategori, menjabarkan ke dalam unit-unit, melakukan sintesa, menyusun ke dalam pola, memilih mana yang penting dan mana yang akan dipelajari, dan membuat kesimpulan sehingga mudah dipahami oleh diri sendirimaupun orang lain".

Untuk menganalisis data kualitatif ini diperlukan beberapa tahapan dan langkah-langkah sebagai berikut, Pertama, Tahapan reduksi data merupakan kegiatan analisis sehingga pilihan-pilihan peneliti tentang bagian mana yang dikode, dibuang, pola-pola mana yang meringkas sejumlah bagian tersebut, 
cerita-cerita berkembang merupakan pilihan analitis (Idrus, 2007: 50). Tahapan reduksi ini dilakukan untuk menelaah secara keseluruhan data yang dihimpun dari lapangan, yang mengenai "Manajemen Pembelajaran Akidah Akhlak di MTsN Samudera Aceh Utara", sehingga dapat ditemukan hal-hal dari objek yang diteliti tersebut

Kedua, Penyajian data adalah penyampaian informasi berdasarkan data yang diperoleh dari MTsN Samudera Aceh Utara sesuai dengan fokus penelitian untuk disusun secara baik, runtut sehingga mudah dilihat, dibaca dan dipahami mengenai suatu kejadian dan tindakan atau peristiwa yang terkait dengan perencanaan Pembelajarann Akidah Akhlak di MTsN Samudera Aceh Utara. Ketiga, Tahap akhir proses pengumpulan data adalah verifikasi dan penarikan kesimpulan, yang dimaknai sebagai penarikan data yang telah ditampilkan. Pemberian makna ini tentu saja sejauh pemahaman peneliti dan interprestasi yang dibuatnya.

Sedangkan untuk teknik pemeriksaan keabsahan data pada penelitian ni, peneliti menggunakan tehnik Triangulasi yang merupakan teknik pemeriksaan keabsahan data yang memanfaatkan sesuatu yang lain diluar data yang telah dikumpulkan (Lexy Moleong,2014: 324).

\section{Hasil Penelitian dan Pembahasan}

Dalam pelaksanaan manjemen pembelajaran akidah akhlak ada beberapa tahap yang harus diperhatikan antara lain yaitu: Pertama, perencanaan pembelajaran akidah akhlak di MTsN Samudera Aceh Utara, Kedua, pelaksanaan pembelajaran akidah akhlak di MTsN Samudera Aceh Utara, Ketiga, penilaian pembelajaran akidah akhlak.

Perencanaan adalah Menentukan apa yang akan dilakukan. Proses belajar mengajar perlu direncanakan agar pembelajaran berlangsung dengan baik dan mencapai hasil yang diharapkan. Setiap perencanaan berkenaan dengan pemikiran tentang apa yang akan dilakukan. Perencanaan dilakukan oleh guruguru yang bersangkutan dalam proses belajara mengajar.

Perencanaan pembelajaran khususnya dalam bidang akidah akhlak meliputi pembuatan program tahunan, didalam program tahunan harus memuat Identitas Pelajaran, Kompetensi Dasar, Materi Pokok dan Alokasi Waktu. Sedangkan dalan program semester harus memuat Identitas Pelajaran, Kompetensi Dasar, Alokasi Waktu, Bulan dan Pekan pelaksanaan. Silabus merupakan ringkasan, ikhtisar, atau pokok-pokok isi atau materi pelajaran. Sedangkan RPP adalah pegangan bagi guru dalam melaksanakan pembelajaran untuk setiap kompetensi dasar.

Setalah adanya perencanaan maka kegiatan belajar mengajar baru bisa dilaksanakan. Pelaksanaan kegiatan pembelajaran akidah akhlak harus sesuai dengan rencana pelaksanaan pembelajaran (RPP) dimana dalam rpp ada terdapat tiga tahap kegiatan pelaksanan nya yaitu kegiatan awal, kegiatan inti dan kegiatan penutup. Berdasarkan hasil observasi dimana sebelum melaksanakan pembelajan siswa diharapkan untuk melaksanakan pembacaan ayat suci Al-Quran yaitu pada surat Yasin setelah itu barulah kegiatan dilakukan. Dalam kegiatan awal, guru melakukan kegiatan membuka pelajaran. 
membuka pelajaran adalah kegiatan yang dilakukan guru untuk menciptakan kondisi atau suasana siap mental dan menimbulkan perhatian siswa terfokus pada hal-hal yang akan dipelajari. Membuka pelajaran dilakukan guru untuk mengkondisikan siswa agar perhatian dan motivasinya tumbuh baik secara fisik maupun psikis memiliki kesiapan untuk melakukan kegiatan pembelajaran, dengan begitu perhatian siswa akan terpusat pada apa yang dipelajarinya.

Setelah kegiatan awal maka selanjutnya kegiatan inti, Didalam kegiatan inti unsur-unsur yang terdapat didalamnya adalah seperti pengelolaan kelas, penggunaann media dan sumber belajar serta penggunaan metode belajar. pada kegiatan ini guru harus bisa mengelola kegiatan pembelajaran sehingga siswa dengan mudah dapat memahami materi yang dipelajarinya, metode pembelajaran juga sangat mempengaruhi kegiatan belajar siswa, dengan adanaya metode pembelajaran maka siswa dengan mudah dapat memahami pembelajaran yang diajarkan.

Kegiatan terakhir yaitu kegiatan penutup, kegiatan ini dimaksudkan untuk memberikan gambaran menyeluruh tentang apa yang telah dipelajari oleh siswa, mengetahui tingkat pencapaian siswa dan tingkat keberhasilan guru dalam proses pembelajaran. dimana pada kegiatan penutup ini guru memberikan kesempatan kepada siswa untuk mengajukan pertanyaan dan terakhir guru dan siswa menyimpulkan pembelajaran yang telah dipelajari.

Hal ini sesuai dengan Permendiknas Nomor 41 Tahun 2007 tentang Standar Proses Satuan Pendidikan Dasar dan Menengah menjelaskan bahwa yang dilakukan guru dalam kegiatan penutup adalah Bersama-sama dengan siswa membuat rangkuman/ kesimpulan pelajaran, Melakukan penilaian dan refleksi terhadap kegiatan yang sudah dilaksanakan secara konsisten dan terprogram, Memberikan umpan balik terhadap proses dan hasil pembelajaran, Merencanakan kegiatan tindak lanjut dalam bentuk pelajaran remedial, program pengayaan, pemberian tugas, baik tugas individual maupun kelompok, Menyampaikan rencana pembelajaran pada pertemuan berikutnya (Rusman, 2010: 92).

Pada tahap akhir yaitu tahap penilaian, pada tahap ini penilaian/evaluasi dilakukan pada dua tahap yaitu pada saat proses kegiatan belajar mengajar berlangsung, selanjutnya penilaian dilakukan pada akhir proses kegiatan belajar mengajar. Penilaian/evaluasi dilakukan oleh guru terhadap hasil pembelajaran untuk mengukur tingkat pencapaian kompetensi peserta didik, serta digunakan sebagai bahan penyusunan laporan kemajuan hasil belajar, dan memperbaiki proses pembelajaran. Penilaian dilakukan pada saat proses belajar mengajar terlaksanakan guna untuk melihat sejauh mana siswa mengerti materi yang diajarkan. Selanjutnya penilaian dengan cara ulangan harian, ulanagan praktek dan terakhir ulanagan semester.

Dengan begitu dapat diketahui bahwa Pelaksanaan pembelajaran Akidah Akhlak di MTsN Samudera Aceh Utara sesuai dengan pendapat Gagne dan Briggs yaitu rencana pembelajaran yang baik hendaknya mengandung tiga komponen yang disebut anchor point, yaitu: 1) Tujuan pengajaran, 2) Materi pelajaran/bahan ajar, pendekatan dan metode mengajar, media pengajaran, dan kegiatan pembelajaran, 3) Evaluasi keberhasilan (Abdul Majid, 2009: 96). 
Dari hasil penelitian tersebut maka dapat dikatakan manajemen pembelejaran akidah akhlak yang ada di MTsN Samudera Aceh Utara sudah tergolong memenuhi syarat dan ketentuan dalam proses belajar mengajar ditandai dengan adanya perencanaan pembelejaran, pelaksanaan pembelejaran dan penilaian/ evaluasi pembelajaran.

\section{E. Kesimpulan}

Dari hasil Penelitian yang telah penulis lakukan di MTsN Samudera Aceh Utara mengenai pelaksanaan pembelajaran Akidah Akhlak yang pengumpulan datanya melalui metode observasi, wawancara, dan juga dokumentasi maka dapat diambil kesimpulan sebagai berikut:

Sebelum melaksanakan pembelajaran seorang guru Akidah Akhlak terlebih dahulu membuat perencanaan persiapan mengajar yaitu perangkat pembelajaran antara lain membuat RPP, Silabus yang digunakan sebagai pedoman dalam melaksanakan pembelajaran. Pelaksanaan pembelajaran Akidah Akhlak meliputi kegiatan pendahuluan, kegiatan inti, dan di akhiri dengan kegiatan penutup. Selanjutnya penilaian, penilaian/Evaluasi di laksanakan untuk mengukur tingkat kemampuan siswa dan tingkat pencapaian materi pelajaran dengan memberikan pertanyaan dan tugas, baik tugas yang berupa tugas individu maupun kelompok. Penilaian/Evaluasi yang digunakan oleg guru Akidah Akhlak menggunakan test tertulis dan test non tertulis.

Sehingga dapat dikatakan bahwa pelaksanaan manajemen pembelajaran di MTsN Samudera Aceh Utara tergolong memenuhi persyaratan dengan adanya perencanaan pembelajaran, Pelaksanaan pembelajaran dan terakhir penilaian/ evaluasi pembelajaran

\section{BIBLIOGRAFI}

Abdul Majid. (2009), Perencanaan Pembelajaran Mengembangkan Standar Kompetensi Guru, Bandung, PT RemajaRosdakarya.

Drost, J.J.S. (1994) Proses Pembelajaran sebagai Proses Pendidikan, Jakarta: Gramedia Widiasarana Indonesia.

Djam'an Satori dan Aan Komariah. (2011), Metode Penelitian Kualitatif, Bandung: Alfabeta.

E. Mulyasa. (2002), Manajemen Berbasis Sekolah, Bandung: Remaja Rosdakarya.

Ismail SM. (2009), Strategi Pembelajaran Agama Islam Berbasis PAIKEM, Semarang: Media Group.

Muhaimin. (2004), Wacana Pengembangan Pendidikan Islam, Surabaya: Pustaka Pelajar.

Malayu, Hasibuan. (2004), Dasar-dasar perbankan, Jakarta: Bumi Aksara.

Moleong, Lexy J. (2007), Metodologi Penelitian Kualitatif, Bandung: Remaja Rosdakarya,

Nazarudin. (2007), Manajemen Pembelajaran: Implementasi Konsep, Karakteristik dan Metodologi Pendidikan Agama Islam di Sekolah Umum, Yogyakarta: TERAS.

Rusman. (2010), Model-Model Pembelajaran Mengembangkan Profesionalisme Guru, Jakarta: Rineka Cipta.

Syaiful Sagala. (2003), Konsep dan Makna Pembelajaran, Bandung: Alfabeta.

Al-Madãris, Volume 2 (2), 2021 
Supriyadi. (2011), Strategi Belajar Mengajar, Yogyakarta: Cakrawala Ilmu.

Sugiono. (2003), Memahami Penelitian Kualitatif, Bandung: Alfabeta.

Sugiyono. (2009), Metode Penelitian Kualitatif dan ReD, Bandung: Alfabeta.

Yunahar Ilyas. (1992), Kuliah Aqidah Islam, Yogyakarta: Lembaga Pengkajian dan Pengamalan Islam

Zainal Arifin. (2012), Evaluasi Pembelajaran, Bandung: PT Remaja Rosdakarya. 